\title{
Enamel Hypoplasia in a Litter of Rats with Alloxan-Induced Diabetes Mellitus
}

\author{
Yara Teresinha Corrêa SILVA-SOUSA ${ }^{1}$ \\ Luiz Cesar PERES ${ }^{2}$ \\ Milton Cesar FOSS 3 \\ ${ }^{1}$ Faculty of Dentistry, UNAERP, Ribeirão Preto, SP, Brazil \\ ${ }^{2}$ Department of Pathology, ${ }^{3}$ Department of Internal Medicine, Faculty of Medicine of Ribeirão Preto, \\ University of São Paulo, Ribeirão Preto, SP, Brazil
}

\begin{abstract}
Enamel hypoplasia is an important clinical problem commonly seen in children born to diabetic women. We aimed to characterize the enamel hypoplasia in Wistar rats born to alloxan-induced diabetes mellitus rats. Groups consisted of pregnant rats supplemented (ISDR) or not (NISDR) with insulin and controls, in which sterile saline solution was administered instead of alloxan or insulin. The mandibular incisors of one-month-old rats born to these mothers were analyzed. Whitish defective enamel was found macroscopically in both experimental groups (ISDR $=37.5 \%$, NISDR $=33.3 \%$ ) but not in the control group. Mild to severe enamel hypoplasia was observed by scanning electron microscopy (ISDR $=93.8 \%$; NISDR $=100 \%$, control $=4.2 \%$ ). The severity of hypoplasia correlated positively with the maternal level of blood glucose. In conclusion, the intensity of enamel hypoplasia in the teeth of the litter born to alloxan-induced diabetic rats was variable and was dependent on the glycemic level of the pregnant rat.
\end{abstract}

Key Words: enamel hypoplasia, alloxan, maternal diabetes, diabetes mellitus.

\section{INTRODUCTION}

Diabetes mellitus is a heterogeneous clinical syndrome characterized by endocrine and metabolic changes that affect homeostasis. The main endocrine problem is partial or total insulin deficiency, leading to profound changes in metabolism of carbohydrates, proteins and lipids. From the frequent association of diabetes mellitus and pregnancy, a clinical class termed gestational diabetes mellitus has emerged, which includes patients who develop or are first diagnosed during pregnancy with diabetes mellitus or glucose intolerance (1).

The hyperglycemic state during pregnancy has long been recognized as deleterious to fetal development, increasing the risk of birth defects (2,3). Although the control of hyperglycemia in patients with gestational diabetes or diabetes mellitus type I has improved in recent years reducing perinatal morbidity and mortality, birth defects have persisted and are now the most important cause of morbidity in children born to diabetic mothers (4).
Enamel hypoplasia in primary teeth of children born to diabetic mothers has been reported (5), although there is a lack of research on the etiopathogenesis and morphology of this condition both in human and experimental animals. Thus, we proposed to determine and characterize morphologically the enamel disorders in the incisor teeth of rats born to mothers with experimentally induced diabetes mellitus.

\section{MATERIAL AND METHODS}

Diabetes mellitus was induced in 33 young white Wistar rats, weighing 180 to $200 \mathrm{~g}, 1-2$ weeks prior to mating by intravenous injection of $40 \mathrm{mg} / \mathrm{kg}$ of alloxan in the dorsal tail vein. To prevent high infertility and fetal loss, these diabetic rats were supplemented with a daily subcutaneous injection in the dorsum of 1 unit $\mathrm{NPH}-$ insulin until mating. This group was then subdivided into 2 groups: 1 group $(\mathrm{N}=26)$ supplemented with 1 unit of NPH-insulin throughout pregnancy (ISDR) and the other group $(\mathrm{N}=7)$ with no supplementation 
(NISDR). To prevent high mortality in the latter group animals with a lesser degree of hyperglycemia were selected. The control group consisted of 9 rats with the same characteristics in which saline solution substituted the alloxan and insulin.

The rats were from the Central Animal House, FMRP-USP (Ribeirão Preto, SP, Brazil). They were kept in groups of 5 animals in metal cages for 1 week for adaptation. Mating was induced by placing 1 male rat in each cage with 5 female rats for 6 days. After this period the female rats were separated and transferred to plastic cages where they were kept until the end of the study. Rats that did not become pregnant were discarded. Water and commercial rat food were offered ad libitum. The rats were kept on a 12-h light-dark cycle at 22$24^{\circ} \mathrm{C}$.

Glucose blood levels were measured by the glucose oxidase method in all rats at predetermined periods: $24 \mathrm{~h}$ prior to alloxan injection, $24 \mathrm{~h}$ after injection, before mating, 15 days after mating and immediately before sacrifice. Blood was taken from the dorsal vein of the tail after a 2-h fasting period, with the animals kept in a heating cage for $5 \mathrm{~min}$. Animals which did not present hyperglycemia were discarded with their litter.

The rats were kept with their litter for 1 month after which they were sacrificed by ethyl ether inhalation. The mandible from each young rat of the litter was removed and sectioned in the anterior segment to free the crowns of the incisor, taking care not to damage it to avoid artifacts. The teeth were properly identified and fixed in Karnovsky's solution for $48 \mathrm{~h}$.

Before scanning electron microscopy (SEM) preparation, the teeth were cleaned by spraying with water for 2 to $3 \mathrm{~min}$, followed by a bath in a solution of $1 \%$ sodium lauryl sulfate for $30 \mathrm{~min}$. They were then

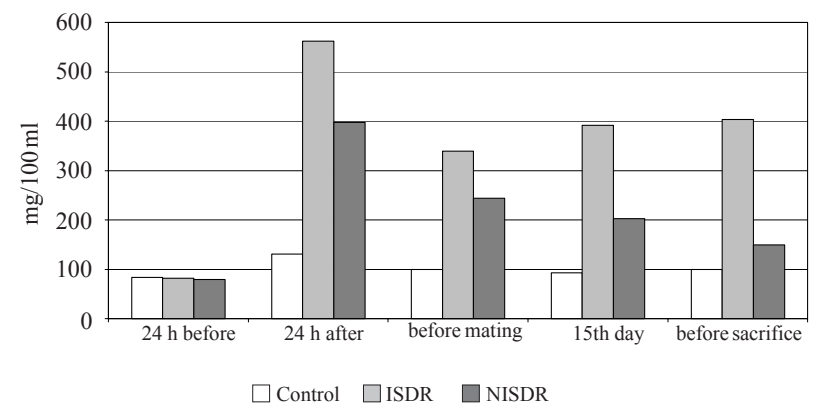

Figure 1. Blood glucose levels of rats during the study. brushed with rubber without any abrasive substance. SEM processing began with dehydration in 3 consecutive 2-h baths in absolute ethanol followed by a $12-\mathrm{h}$ bath. The teeth were then removed from the ethanol and placed on filter paper in an oven for $4 \mathrm{~h}$ at $40^{\circ} \mathrm{C}$ after which they were sputter-coated with gold for three 3min cycles (Emitech K650, Germany). Analysis was performed under a Zeizz DSM-940A (Stuttgart, Germany) scanning electron microscope.

\section{RESULTS}

Blood glucose levels of the 3 groups of rats are shown in Figure 1. One control rat did not become pregnant and was discarded. The remaining 8 had a total of 91 rats, 1 of which died during the neonatal period $(1.1 \%)$. Three rats from each mother were chosen at random for sacrifice for a total of 24 rats. Although both incisors from each rat were analyzed by SEM we considered only 1 tooth per rat because the same defect was present in both. The ISDR group began with 26 animals but 4 (15.4\%) did not develop diabetes and were discarded. Of the remaining 22, $18(81.8 \%)$ became pregnant, $1(4,5 \%)$ of which died during the study. A total of 161 rats were born to these 17 animals, but $17(10.5 \%)$ died just before birth, all from the same mother. We chose 3 rats at random from each mother, for a total of 48 rats. The NISDR group began with 7 animals but only $4(57.1 \%)$ became diabetic and from these $2(50 \%)$ became pregnant, resulting in 20 young rats. We chose 3 rats at random from each mother, for a total of 6 rats.
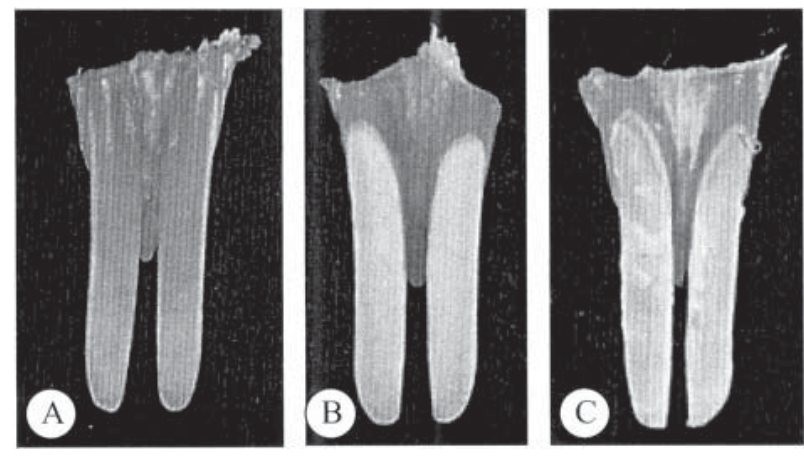

Figure 2. Gross features of teeth. Homogeneous surface of teeth revealing normal transparent enamel is seen in control rats (A). Severe hypoplasia seen in both ISDR (B) and NISDR (C) groups showed irregular, chalky, whitish altered enamel. 
Control teeth seen under a dermatological lens exhibited a yellow homogeneous smooth surface (Figure 2A) that was also seen in 30/48 (62.5\%) of ISDR and $4 / 6(66.7 \%)$ of NISDR teeth. Some teeth from the latter groups showed an irregular whitish opaque porous surface (Figure $2 B),($ ISDR $=18 / 48$, $37.5 \%$; NISDR $=2 / 6,33.3 \%$ ). Focal absence of enamel was observed in $4 / 18(22.2 \%)$ of the ISDR group (Figure $2 \mathrm{C}$ ).

The teeth were classified by SEM as normal or
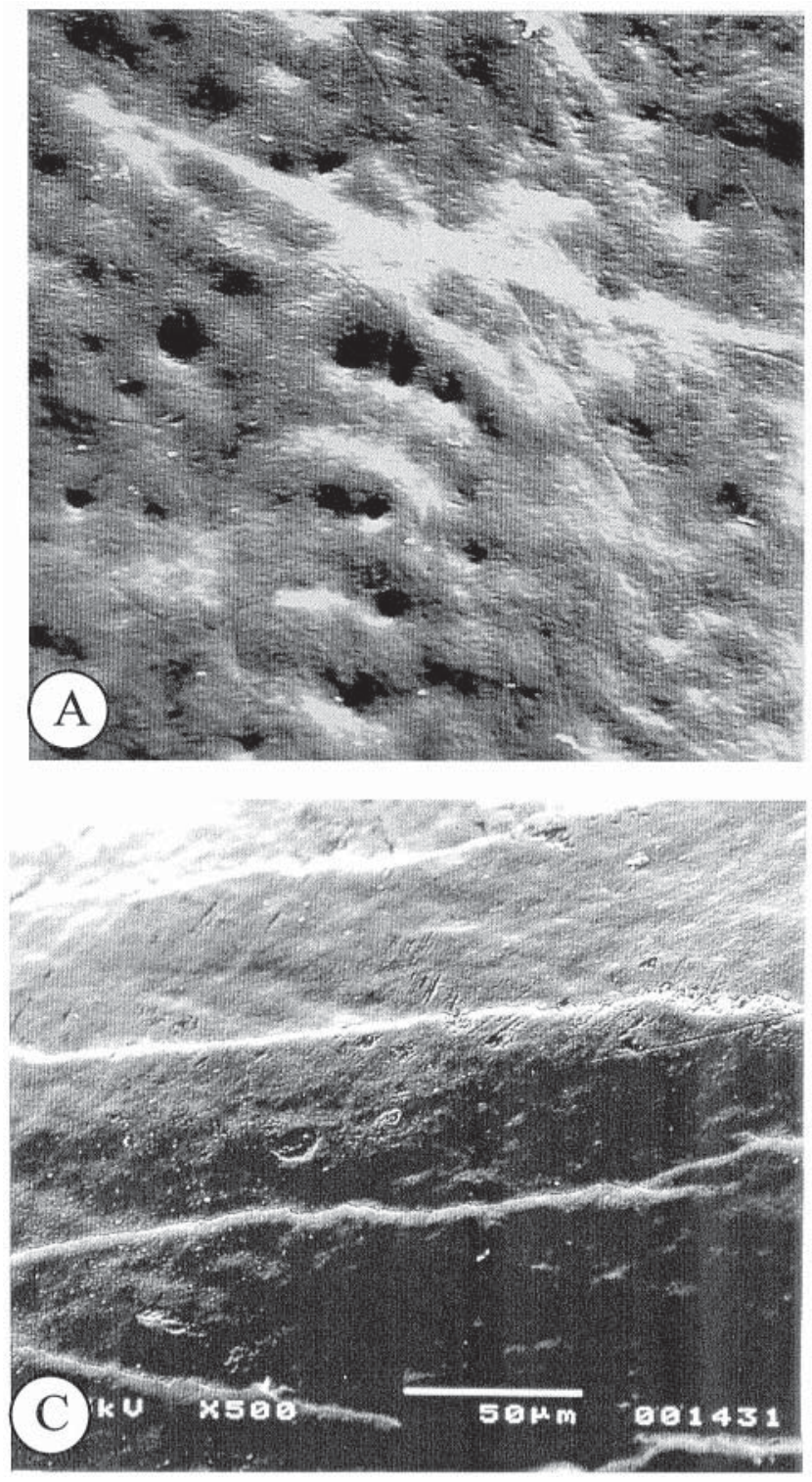

with defects that ranged from mild to severe. Normal enamel was characterized by a homogeneous, regular, smooth surface with small and regular round pits of varying depth, corresponding to Tomes' processes of ameloblasts (Figure 3A,B). Mild defects were characterized by the presence of occasional irregular and superficial depressions with a rough base (Figure 3C,D). Lesions of moderate defects were more widespread and intense, with variable size, form and depth giving a rough appearance to the affected areas (Figure 4). Se-
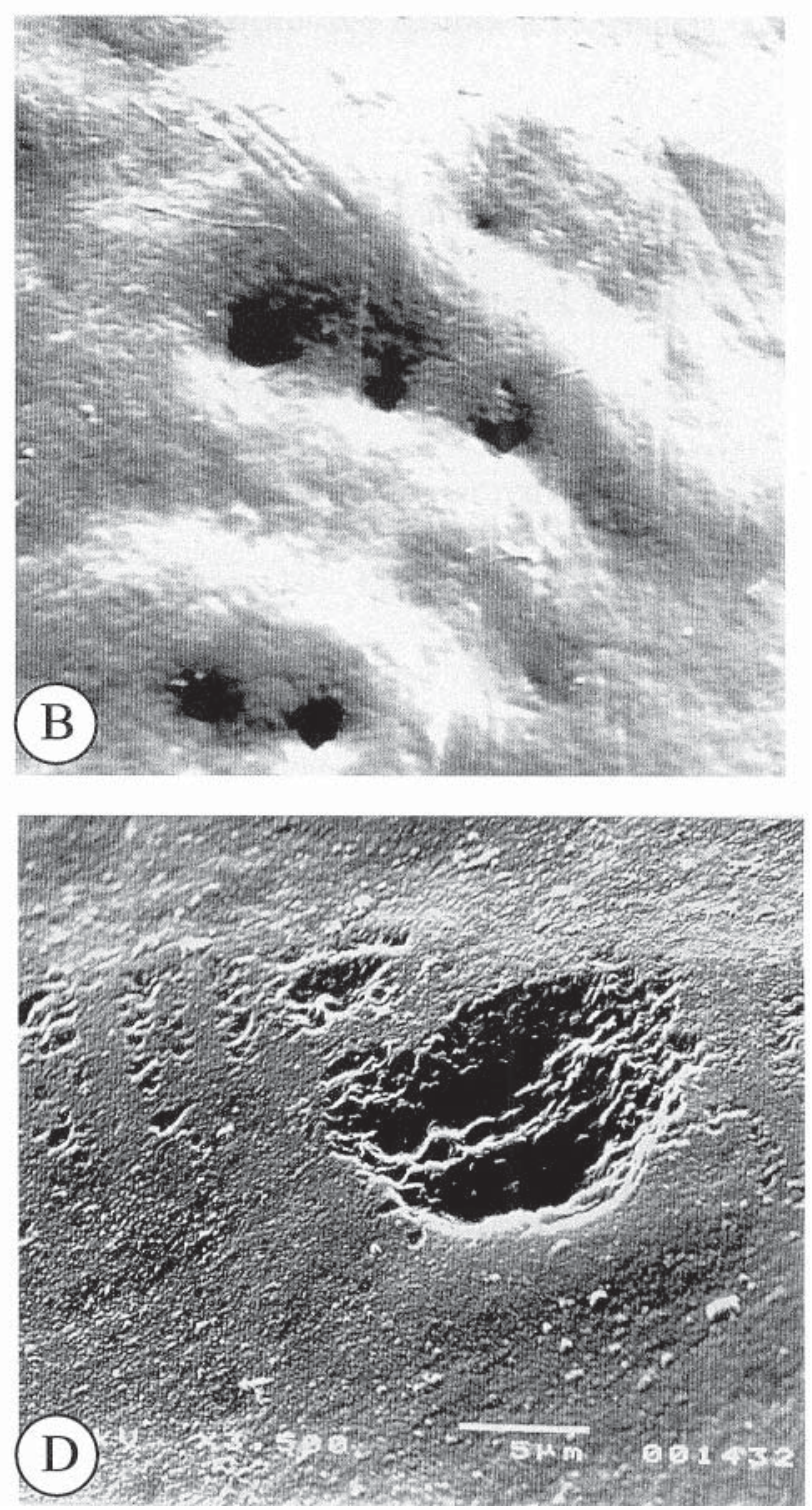

Figure 3. Scanning electron microscopy of the normal enamel surface showing the presence of small circular pits corresponding to the Tomes' processes of ameloblasts (A and B). Scanning electron microscopy of the enamel surface showing mild hypoplasia with a relatively homogenous surface and a few superficial depressions (C and D). Original magnification: A - 2000X; B - 5000X; C - 500X; D - 3500X. 
vere hypoplasia was characterized by intense, generalized defects in which regular crystalloid structures in a basket-weave pattern intermixed with filaments could be seen (Figure 5).

Using SEM, only $1(4.2 \%)$ of the 24 control teeth exhibited mild hypoplasia. In the ISDR group, 3 (6.2\%) teeth were normal whereas mild hypoplasia was seen in $17(35.4 \%)$, moderate in $21(43.8 \%)$ and severe in 7 $(14.6 \%)$. In the NISDR group, there were no normal teeth. Mild hypoplasia was seen in $4(66.6 \%)$, moderate in $1(16.7 \%)$ and severe in $1(16.7 \%)$.
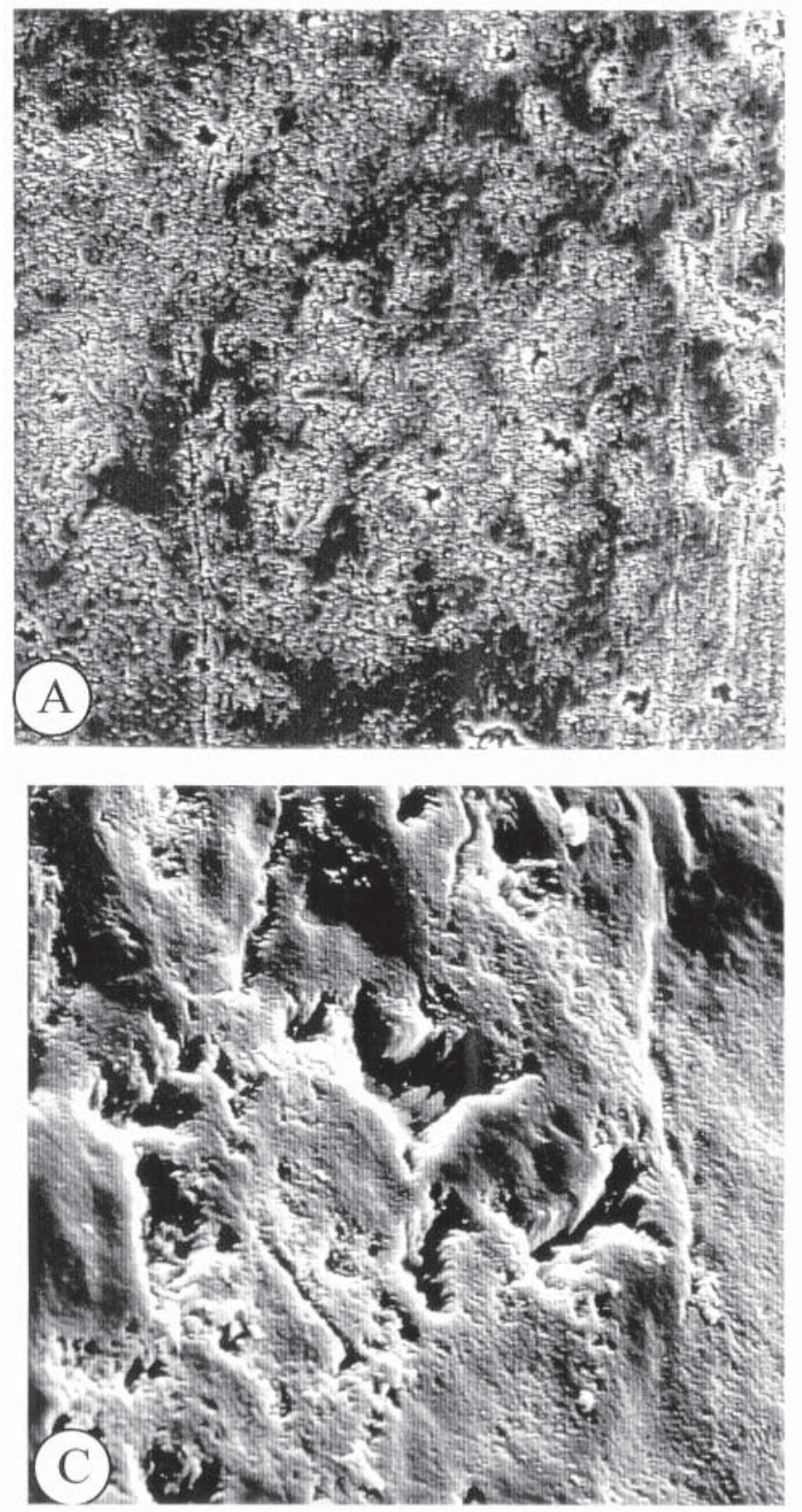

\section{DISCUSSION}

Birth defects associated with maternal diabetes mellitus in experimental animals have long been reported in the literature $(3,6-8)$. Diabetes may be experimentally produced surgically by pancreatectomy (9), or chemically by administration of streptozotocin (10) or alloxan (11). We chose the latter because it is easy to perform, results in a high percentage of diabetic rats, is similar to human disease and has been widely used at our institution.
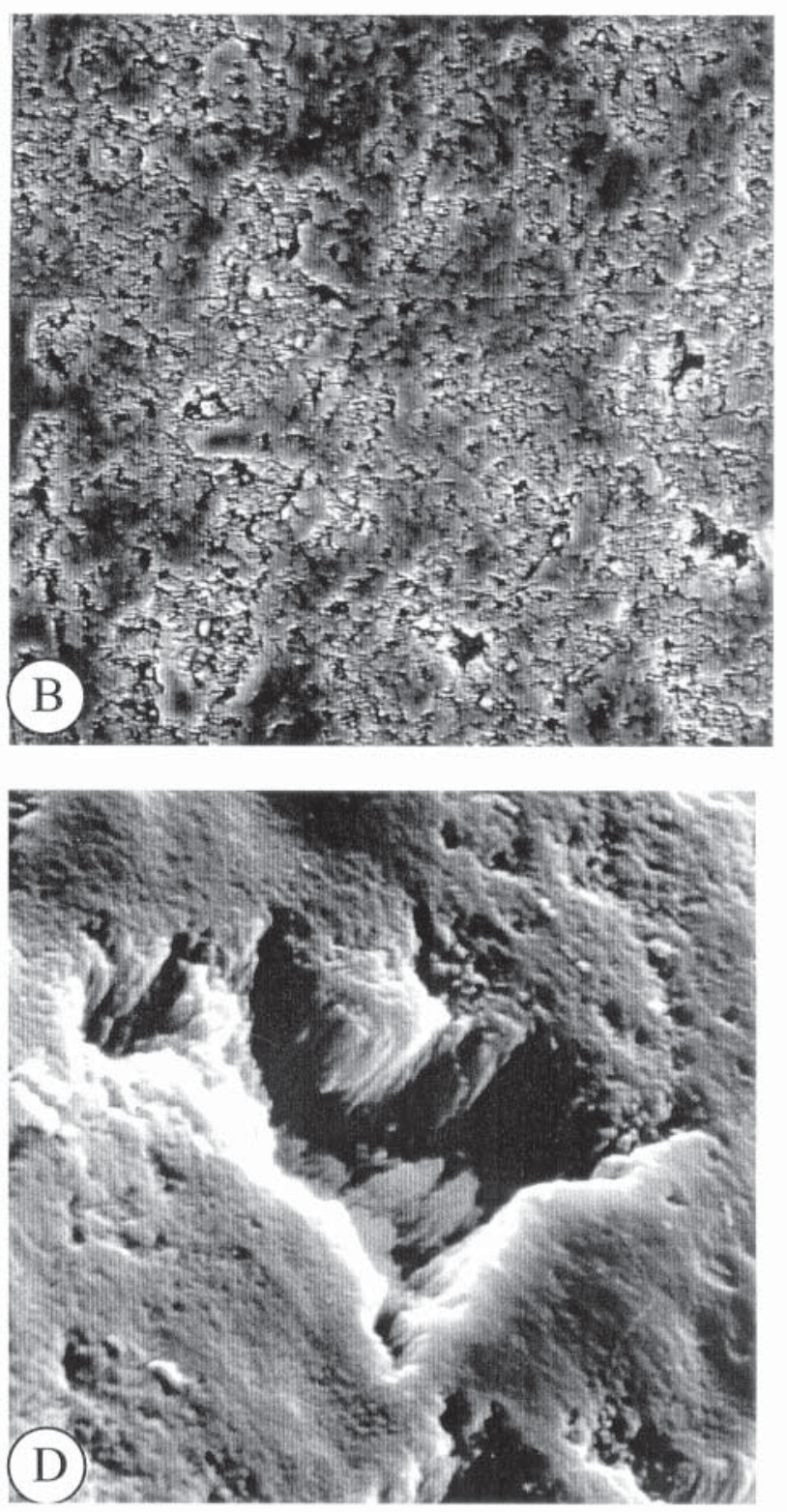

Figure 4. Scanning electron microscopy of the enamel surface showing moderate hypoplasia with depressions of variable size, form and depth. Original magnification: A - 500X; B - 1000X; C - 2000X; D - 5000X. 
The method used was effective in producing hyperglycemia in $78.8 \%$ of alloxan-treated rats. This hyperglycemia results from selective necrosis of $\beta$-cells of Langerhans' islands in the pancreas. There is immediate hyperglycemia, which peaks in 2-3 $\mathrm{h}$, followed by a transitory hypoglycemia due to cell necrosis. A permanent hyperglycemia is usually present thereafter due to insulin deficit (11).

Diabetes mellitus was induced prior to mating to
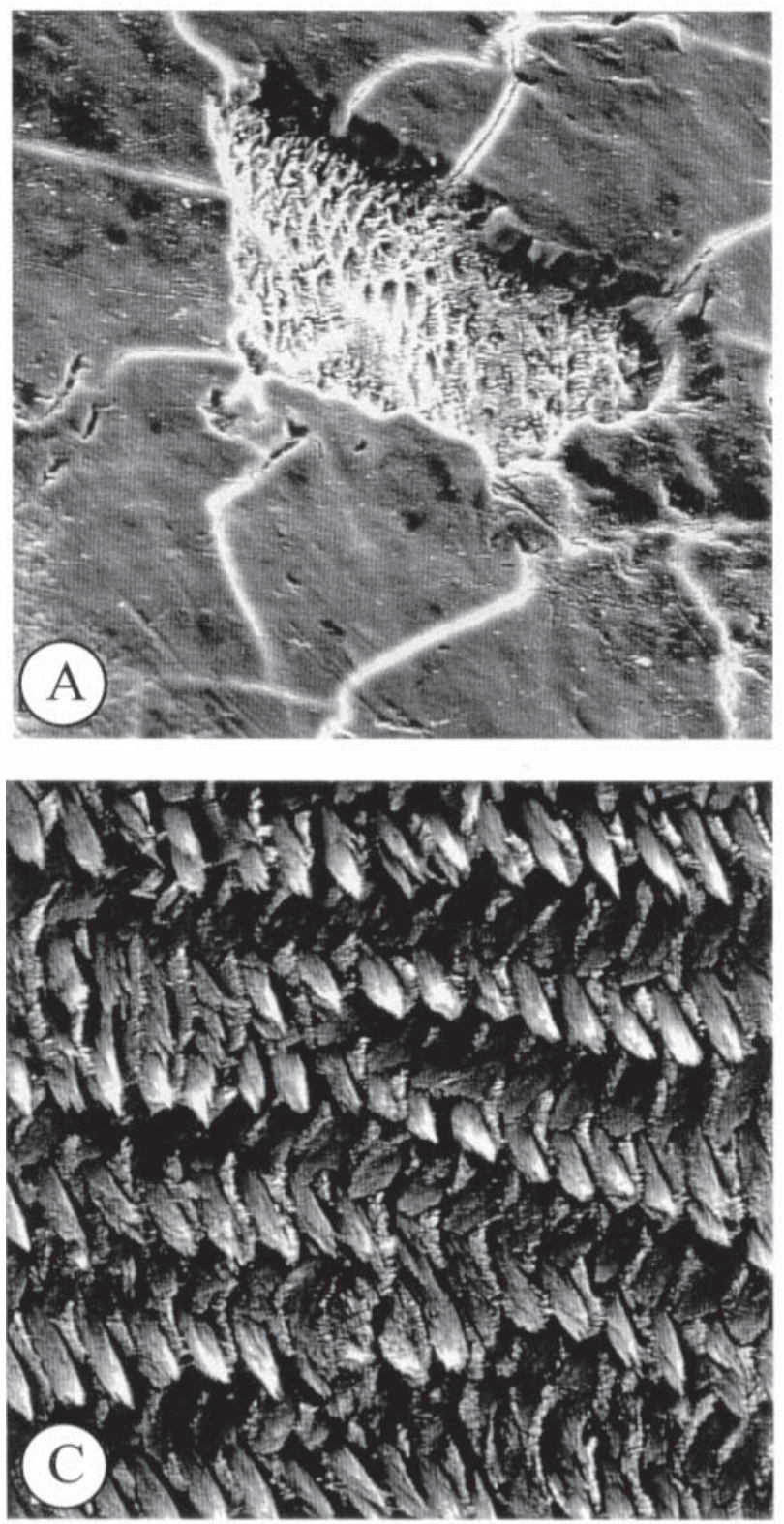

prevent the deleterious acute toxic effects of alloxan on the fetuses (12). Insulin was supplemented until after mating to avoid the negative effects of hyperglycemia on fecundation. However, failure to achieve pregnancy was higher (23.1\%) in both ISDR and NISDR groups than in the control (11.1\%), as previously reported by Kim et al. (12).

There is much evidence in the literature of the occurrence of birth defects induced by diabetes melli-
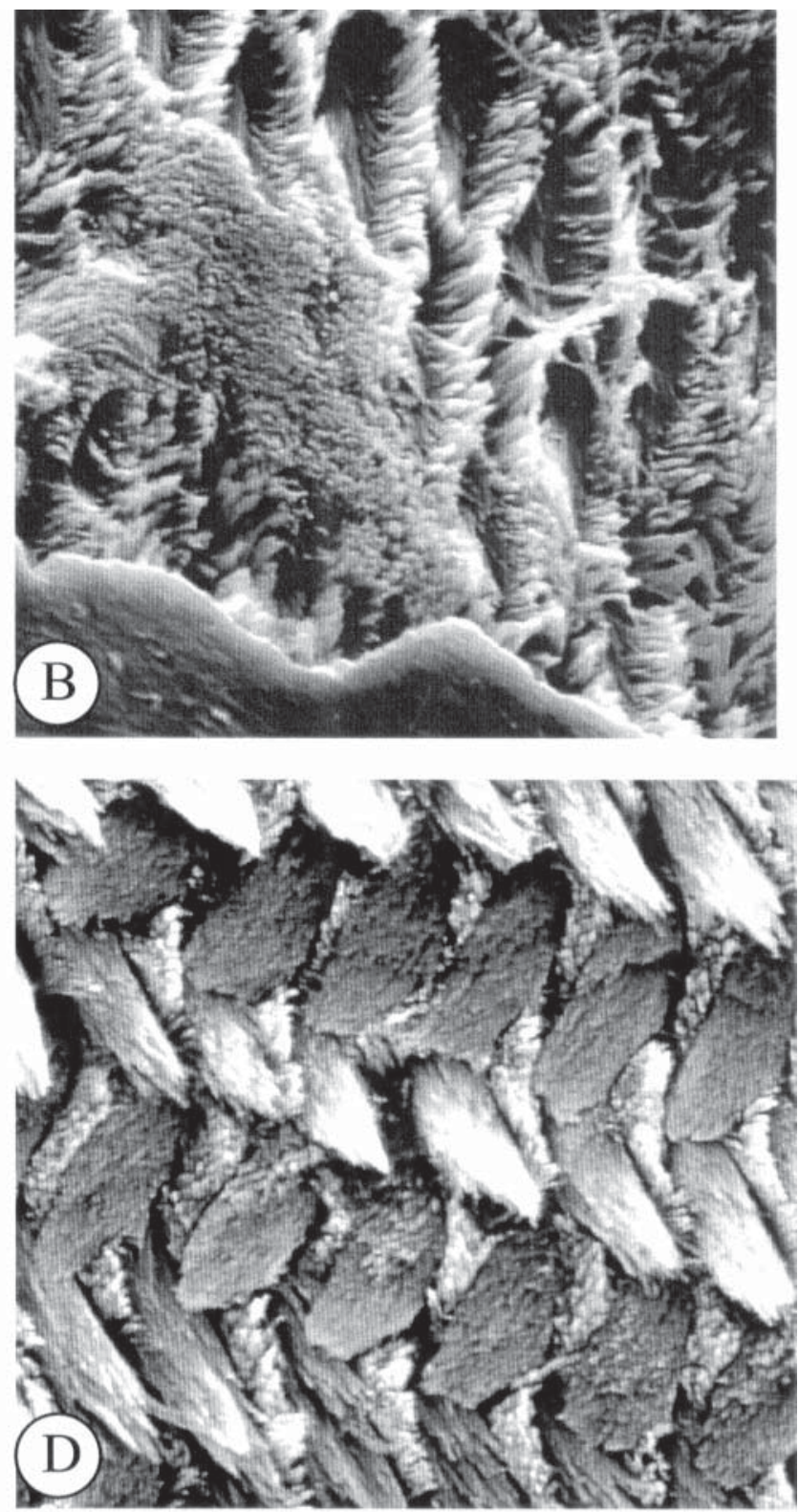

Figure 5. Scanning electron microscopy of the enamel surface showing severe hypoplasia (A and B) with regular crystalloid structures intermixed with filaments giving a basket-weave pattern (C and D). Original magnification: A - 1000X; B - 5000X; C -2000X; D $5000 \mathrm{X}$. 
tus, both in humans $(2-4,7)$ and animals $(3,6)$, including agnathia, cleft palate, cranioschisis, craniorhachischisis and occult spina bifida. Horii et al. (3) observed that the type and frequency of birth defects are dependent on the period of induction of alloxan diabetes mellitus, being more intense at the beginning of gestation than at late gestation. Eriksson et al. (7) have also reported that the teratogenic effect of maternal diabetes on development manifests during embryogenesis and that correction of metabolic disturbances with insulin at the critical stages is protective to the litter. In this study, in spite of the high blood glucose level in many of the animals during gestation we did not find any rat with birth defects among those that survived. In fact, because the aim of this study was to induce enamel hypoplasia and not other types of birth defects, we did not check all rats as soon as they were born. It is possible that defective newborn rats had been eaten by the mother.

There is evidence that enamel hypoplasia is more likely to be found in primary teeth of children born to diabetic mothers $(5,13)$. Karim (8) studied the effect of alloxan on the ameloblasts of enamel secretion. He found some morphologic alterations in these teeth that could be related to both alloxan and hyperglycemia and others only to hyperglycemia. In the present study, we have identified many defects in the enamel of the litter of rats with alloxan-induced diabetes mellitus in which there was only the effect of hyperglycemia because alloxan was administered many days before mating.

The macroscopic aspect of the teeth in this study was very similar to that seen in human teeth with enamel hypoplasia. The opaque, whitish, chalky enamel is suggestive of poor mineralization, which produces a rather porous surface. The areas of the crown of the teeth without enamel indicate defective production of organic matrix, reducing thickness. Shaffer et al. (14) reported that in cases with an absence of enamel there must be a prolonged disturbance in ameloblast function.

The majority of the studies on enamel hypoplasia are devoted to clinical rather than to morphologic and ultrastructural features. SEM was extremely valuable in the study of this condition because only severe defects of the enamel can be identified macroscopically or even with the aid of a magnifying lens.

The frequency of enamel hypoplasia was highly dependent on the severity of hyperglycemia in the mother in both groups. Hypoplasia was more intense in the ISDR group compared to the NISDR group possibly because the hyperglycemia in those animals was higher in spite of insulin supplementation.

Moderate hypoplasia as observed in this study was similar to that described by Bäckman et al. (15) in primary teeth with amelogenesis imperfecta and also by Motoyama et al. (16) in neonatal teeth from patients with cleft lip and palate.

The most severe form of hypoplasia was seen in the teeth that were macroscopically abnormal, with a spotted or total whitish surface. The conoid structures arranged in orderly arrays of opposite orientation, like a basket weave, represented enamel prisms intermixed with interprismatic substance, suggesting that the prismless layer was not formed. Motoyama et al. (16) refers to similar findings as representative of prismless and prismatic areas in neonatal teeth from patients with cleft lip and palate. Mjör and Fejerskov (17) reported that teeth demineralized with acid for studies on the adhesion of compound resins show surface alterations by SEM similar to the ones found in this investigation. Since we did not use demineralizing agents these defects may be a consequence of maternal hyperglycemia during pregnancy. This interpretation is supported by our observation that the severity of the defects is correlated with the level of maternal hyperglycemia. Alloxan is not related to these findings because it was used only once, 1-2 weeks before mating.

In both human and experimental diabetes, problems are not only related to hyperglycemia but to many intracellular metabolic disturbances in consequence to the lack of glucose in the majority of cells. Metabolites produced in these processes may interfere in other biochemical pathways or induce morphologic alterations in distant places (18). Magnesium disorders may play some role in this model because it is known that hypomagnesemia occurs in diabetic animals (19), as well as in diabetic women and their neonates (20). Calcium concentration in the blood inversely reflects the levels of magnesium in both human (20) and animals (19). In an experiment in which rats were fed a diet poor in magnesium, there was a fall in the content of this element but not of bone calcium (19), but there are no data on dental mineralization so far.

The present study was not directed at the detection of the complex pathogenesis of enamel hypoplasia but rather to its morphologic characterization. Further studies will be needed in order to assess possible mechanisms involved in this lesion. 
We conclude that the present study demonstrates that alloxan-induced diabetes mellitus in rats before mating is an efficient model with the advantages of low cost, easily reproducible procedure that requires simple facilities. Insulin supplementation is necessary to minimize animal loss as well as to prevent infertility. The deleterious effects of alloxan are avoided by its single injection 1-2 weeks before mating. Enamel hypoplasia, achieved in a high proportion of cases with varying intensity, is at least partly dependent on maternal blood glucose levels and correlates to findings in human cases.

\section{RESUMO}

A hipoplasia do esmalte dental é um problema clínico importante, freqüentemente visto em filhos de mães diabéticas. Este estudo objetivou caracterizar a hipoplasia do esmalte dental em ratos Wistar nascidos de mães com diabetes mellitus aloxânico. Os grupos consistiram de ratas com diabetes mellitus aloxânico suplementadas (ISDR) ou não com insulina (NISDR) e controles. Os incisivos mandibulares da prole destes animais com um mês de vida foram analisados. Esmalte dental brancacento e defeituoso foi encontrado macroscopicamente em ambos os grupos experimentais (ISDR $=37,5 \%$, NISDR $=33,3 \%$ ), mas não no grupo controle. Hipoplasia leve a acentuada do esmalte dental foi observada por microscopia eletrônica de varredura (ISDR = $93,8 \%$, NISDR $=100 \%$, controle $=4,2 \%$ ). A intensidade da hipoplasia correlacionou-se positivamente com os níveis séricos de glicose maternos. Em conclusão, a intensidade da hipoplasia do esmalte dental nos dentes de prole de ratas com diabetes aloxânico foi variável e dependente da glicemia materna.

\section{REFERENCES}

1. Foss MC. Diabetes mellitus - Conceito, diagnóstico e classificação. Medicina, Ribeirão Preto. 1989;22:54-61.

2. Driscoll SG, Benirschke K, Curtis GW. Neonatal deaths among infants of diabetic mothers. Amer J Dis Child 1961;98:818-823.

3. Horii KI, Watanabe GI, Ingalls TH. Experimental diabetes in pregnant mice. Prevention of congenital malformations in offspring by insulin. Diabetes 1966;15:194-204.

4. Ryan EA, Tobin BW, Tang J, Finegood DT. A new model for study of mild diabetes during pregnancy. Syngeneic islet-trans- planted STZ-induced diabetic rats. Diabetes 1993;42:316-323.

5. Adler $\mathrm{P}$, Wegner $\mathrm{H}$, Bohátka L. Influences of age and duration of diabetes on dental development in children. J Dent Res 1973;52:535-537.

6. Takano K, Nishimura H. Congenital malformations induced by alloxan diabetes in mice and rats. Anat Rec 1967;158:303-312.

7. Eriksson UJ, Dahlström E, Hellerström C. Skeletal malformations in the offspring of diabetic rats after intermittent withdrawal of insulin in early gestation. Diabetes 1983;32:1141-1145.

8. Karim AC. An ultrastructural study of the effect of a diabetogenic dose of alloxan on the secretory ameloblasts of the rat incisor. Am J Anat 1983;166:83-98.

9. Migliorini RH. Pancreatectomia total no rato. Tempo de aparecimento de defeitos metabólicos nos tecidos hepáticos, adiposo e muscular. Ribeirão Preto, Thesis (Livre-Docência). Faculdade de Medicina de Ribeirão Preto, Universidade de Ribeirão Preto. 1962.

10. Brenna O, Qvigstad G, Brenna E, Waldum HL. Cytotoxity of streptozotocin on neuroendocrine cells of the pancreas and the gut. Dig Dis Sci 2003;48:906-910.

11. Goldner MG, Gomori G. Studies on the mechanism of alloxan diabetes. Proc Soc Exp Biol Med 1944;55:73-75.

12. Kim JN, Runge W, Wells LJ, Lazarow A. Effects of experimental diabetes on the offspring of the rat. Diabetes 1960;9:396-404.

13. Grahnén H, Möller EB, Bergström AL. Maternal diabetes and changes in the hard tissues of primary teeth. II. A further clinical study. Caries Res 1968;2:333-337.

14. Shafer WG, Hine MK, Levy BM. A Textbook of Oral Pathology. 4th ed, Philadelphia: WB Saunders. 1983.

15. Bäckman B, Anneroth G, Hörstedt P. Amelogenesis imperfecta: a scanning electron microscopic and microradiographic study. J Oral Pathol Med 1989;18:140-145.

16. Motoyama LCJ, Lopes LD, Watanabe I. Natal teeth in cleft lip and palate patients: a scanning electron microscopy study. Braz Dent J 1996;7:115-119.

17. Mjör IA, Fejerskov O. Embriologia e Histologia Oral Humana. São Paulo: Panamericana, 1990.

18. Crawford JM, Cotran RS. The pancreas. In: Robbins Pathologic Basis of Disease. 5th ed. Cotran RS, Kumar V, Robbins SL. eds. Philadelphia: WB Saunders, 1994, pp. 910-918.

19. Rude RK, Kirchen ME, Gruber HE, Stasky AA, Meyer MH. Magnesium deficiency induces bone loss in the rat. Mineral and Electrolyte Metabolism 1998;24:314-320.

20. Brodsky M, Elin R, Giles TD, Gupta R, Lefebvre PJ, Lowenthal DT, Mimouni F, Nadler J, Paolisso G, Resnick LM, Seelig M, Wacker WEC, Whang R, DeFelice S, Garber A, Kahn R. Magnesium supplementation in the treatment of diabetes. Diabetes Care 1996;19:S93-S95. 
MARCONDES

E GALDINO

EXCLUSIVE REPRESENTATIVE FOR THE PRODUCTS:

- Autoclaves, Sterilizers

- Driers

- Handpieces

- High-speed handpieces

- Curing light

- X-ray units

- Dental operating lights

- Micromotors

- Dark box for x-ray revelation

- Lead apron

- Drill box

- Temporizator

- Multidoppler ultrasound detector

- Fetal transducer $5.0 \mathrm{MHz}$

- Vascular transducer $5.0 \mathrm{MHz}$

- Vascular transducer $10.0 \mathrm{MHz}$

- Ultrasonic cleaner

REQUEST FOR CATALOGS AND ORDERS:

Mr. LUIZ MARCONDES

RUA SANTOS, 1251

14075-060 - RIBEIRÃO PRETO - SP - BRASIL

TEL. +55-16-3977-3300 - FAX. +55-16-3977-3307

E-MAIL: odontobras@netsite.com.br 